\title{
Relative Bioavailability of DL and L-Methionine in Broilers
}

\author{
Enric Esteve-Garcia', Daulat Rehman Khan ${ }^{2}$ \\ ${ }^{1}$ IRTA, Mas Bover, Ctra. Reus al Morell, Km 3.8, E-43120 Constantí, Spain \\ ${ }^{2} \mathrm{CJ}$ Europe GmbH, Ober der Roeth 4, 65824 Schwalbach, Germany \\ Email: enric.esteve@irta.cat
}

How to cite this paper: Esteve-Garcia, E. and Khan, D.R. (2018) Relative Bioavailability of DL and L-Methionine in Broilers. Open Journal of Animal Sciences, 8, 151-162. https://doi.org/10.4236/ojas.2018.82011

Received: December 20, 2017

Accepted: April 9, 2018

Published: April 12, 2018

Copyright (c) 2018 by authors and Scientific Research Publishing Inc. This work is licensed under the Creative Commons Attribution International License (CC BY 4.0).

http://creativecommons.org/licenses/by/4.0/

\begin{abstract}
Studies on the relative bioavailability (RBV) of DL-Methionine (DL-Met) to L-Methionine (L-Met) have produced variable results. An experiment was conducted to determine the RBV of DL to L-Met. A total of 2268 1-day old male chicken were housed in 54 floor pens ( 42 bird/pen). There were 9 treatments ( 6 repetitions) including the basal diet (BD). The BD was deficient in Met content with $0.27,0.26$ and 0.25 in the starter, grower and finisher periods respectively. Four levels of experimental diets for each DL-Met and L-Met were created by supplementing $0.05 \%, 0.10 \%, 0.15 \%$ and $0.20 \%$ of DLor L-Met to the $\mathrm{BD}$. The feeding program consisted of starter $(0-14 \mathrm{~d}, 21 \% \mathrm{CP}$ and $2900 \mathrm{kcal} \mathrm{ME} / \mathrm{kg}$ ), grower (15 - $28 \mathrm{~d}, 20 \% \mathrm{CP}$ and $3000 \mathrm{kcal} \mathrm{ME} / \mathrm{kg}$ ) and finisher period ( $29-37 \mathrm{~d}, 18.5 \% \mathrm{CP}$ and $3050 \mathrm{kcal} \mathrm{ME} / \mathrm{kg}$ ). Chickens and feed were weighed at the end of each age period. Regression coefficients of a common plateau asymptotic regression were used to calculate RBV. Birds responded to gradual increase in Met levels, BW, FCR and ADG were significantly $(P<0.05)$ higher in treatment groups as compared to control. Through the study period ( $37 \mathrm{~d}$ ), the RBVs of DL-Met for BW and FCR were 89 and 77 respectively.
\end{abstract}

\section{Keywords}

Bioavailability, DL-Methionine, L-Methionine, Broilers

\section{Introduction}

Better growth, economy and environment friendly commercial broiler production is limited to the right amount of available amino acids for efficient utilization in animal body. All of the crystalline amino acids supplemented in commercial poultry production are in their natural (L-isomer) form except methio- 
nine (Met), which may be utilized in its synthetic (D- and L-isomers) form in poultry. However, birds have to transform the D-isomer form into L-isomer in order to make it available for protein synthesis and other essential metabolic functions. It is not clear whether this conversion process in $100 \%$ efficient and all of the supplemented D-isomer form is being converted into L-isomer for its further utilization in animal body.

Inefficient intestinal absorption of supplemented Met is one of the factors which may limit its availability to body metabolism. For instance, Esteve-Garcia and Austic [1] observed 1\% higher recovery of DL-Met as compared to L-Met in terminal ileum.

A number of studies have been carried out about the bio-efficiency of D, L and DL-Met. However, their results remained indecisive. Some reports showed that D- and L-Methionine were equivalent [2] [3] [4]. While others showed D-Methionine to be inferior [5] [6]. With regard to L- and DL-Methioine, Grau and Almquist [2], Leveille et al. [4], Gutteridge and Lewis [7] and Dilger et al. [8] showed equal efficacy of L and DL-Met. In contrast, Marret et al. [9], Smith [6], Katz and Baker [10] suggested that L-Met is superior to DL-Met when biological efficacy is compared. Even two reports [9] [11] concluded that D and DL-Met have better bio-efficiency than L-Met alone. Marret et al [9] showed that diets containing large amounts of D-amino acids caused D-methionine to be less efficient, suggesting that the capacity of $\mathrm{D}$-amino acid oxidase could be exceeded.

The goal of the present study was to determine the RBV of two sources of Met (DL vs. L-Met), supplemented at graded levels to practical broiler diets, using growth parameters as response criteria.

\section{Materials and Methods}

\subsection{Animals and Diets}

All animal housing and husbandry conformed to the European Union Guidelines [12] and the protocol was approved by the Ethical Animal Committee of IRTA. A total of 2268 one-day-old male broiler (Ross 308) chickens were distributed into $54\left(4 \mathrm{~m}^{2}\right.$ each) pens. There were six replicates per treatment (42 birds/pen). Standard light and temperature plans were followed [13].

The basal diet was formulated according to nutrient recommendations of Ross 308 [13], however, Met ( $<60 \%$ of Ross requirement) was kept in limiting position. Dietary ingredient composition and analysed nutrient contents are described in Table 1 and Table 2.

The feeding program was divided into three age periods; starter $(0-14 \mathrm{~d})$, grower (15 - $28 \mathrm{~d}$ ) and finisher (29 - $37 \mathrm{~d}$ ). Eight experimental diets were created by supplementing crystalline DL or L-Met to the BD in four graded levels, plus the un-supplemented diet. The calculated values for the experimental diets of DL-Met 1-4 or L-Met1-4 were BD $+0.05,0.10,0.15$ and $0.20 \%$ respectively, based on expected responses to methionine (Esteve-Garcia and Austic [1]; the laboratory analysed levels are shown in Table 3. 
Dietary ingredients and experimental diets were analysed according to AOAC [15] for crude protein (method 968.06), ether extract (method 920.39) and crude ash (method 942.05). The amino acid content of the ingredients was analysed by ion exchange chromatography coupled with post column derivatization and photometric detection according to Neumann and Bassler [16].

Body weight and feed consumption were measured at 14,28 and $37 \mathrm{~d}$ on a pen basis. Dead animals were not taken into account, and their weight was subtracted from the initial weight of the pen, according to the mean weight, or in case the animal was smaller than the initial weight due to disease, its weight at the time of death was subtracted from the initial weight of the pen. Corrected

Table 1. Ingredient composition of basal diet ( $\mathrm{g} / \mathrm{kg}$ as fed basis).

\begin{tabular}{|c|c|c|c|}
\hline Ingredient & Starter & Grower & Finisher \\
\hline Maize & 550.2 & 480.4 & 503.4 \\
\hline Wheat & 60 & 100 & 100 \\
\hline Soybean meal, $48 \% \mathrm{CP}$ & 280 & 224.7 & 200 \\
\hline Full fat extruded soybeans & - & 45 & 38.1 \\
\hline Peas & - & 40 & 52.5 \\
\hline Soy oil & 29.7 & - & - \\
\hline Animal fat & - & 42.8 & 55 \\
\hline Dicalcium phosphate & 19.3 & 15 & 13.5 \\
\hline Calcium carbonate & 7.7 & 7.9 & 7.9 \\
\hline Sodium chloride & 4 & 3.5 & 3.5 \\
\hline L-Glu & 30 & 30 & 15 \\
\hline L-Lys $\mathrm{HCl}$ & 4.8 & 2.7 & 2.7 \\
\hline L-Arg $\mathrm{HCl}$ & 2.3 & 0.5 & 0.8 \\
\hline $\mathrm{L}-\mathrm{Val}$ & 2.6 & 1.4 & 1.4 \\
\hline L-Thr & 1.8 & 0.9 & 1 \\
\hline L-Ile & 2.3 & 1.4 & 1.6 \\
\hline L-Trp & 0.6 & 0.1 & 0.4 \\
\hline Choline chloride & 1 & - & - \\
\hline Mineral and vitamin premix ${ }^{1}$ & 3 & 3 & 3 \\
\hline Maxiban G $160^{2}$ & 0.5 & - & \\
\hline Elancoban $^{3}$ & - & 0.5 & - \\
\hline Ethoxyquin, $66 \%$ & 0.2 & 0.2 & 0.2 \\
\hline
\end{tabular}

${ }^{1}$ Provides per kg feed: vitamin A (E-672) $13500 \mathrm{IU}$; vitamin $\mathrm{D}_{3}$ (E-671) $4800 \mathrm{IU}$; vitamin E (alfa-tocopherol) $45 \mathrm{mg}$; vitamin $B_{1} 3 \mathrm{mg}$; vitamin $B_{2} 9$ mg; vitamin $B_{6} 4.5 \mathrm{mg}$; vitamin $B_{12} 16.5 \mu$; vitamin $K_{3} 3 \mathrm{mg}$; calcium panthotenate $16.5 \mathrm{mg}$; nicotinic acid $51 \mathrm{mg}$; folic acid $1.8 \mathrm{mg}$; biotin $30 \mu \mathrm{g}$; $\mathrm{Fe}(\mathrm{E}-1)$ (from $\mathrm{FeSO}_{4} \cdot 7 \mathrm{H}_{2} \mathrm{O}$ ) 54 mg; I (E-2) (from Ca $\left.\left(\mathrm{I}_{2} \mathrm{O}_{3}\right)_{2}\right) 1.2 \mathrm{mg}$; $\mathrm{Co}(\mathrm{E}-3)$ (from $2 \mathrm{CoCO}_{3} \cdot 3 \mathrm{Co}(\mathrm{OH})_{2} \cdot \mathrm{H}_{2} \mathrm{O}$ ) $0.6 \mathrm{mg} ; \mathrm{Cu}(\mathrm{E}-4)$ (from Cu$\mathrm{SO}_{4} \cdot 5 \mathrm{H}_{2} \mathrm{O}$ ) $12 \mathrm{mg} ; \mathrm{Mn}(\mathrm{E}-5)$ (from MnO) $90 \mathrm{mg} ; \mathrm{Zn}(\mathrm{E}-6)$ (from ZnO) $66 \mathrm{mg}$; Se (E-8) (from $\mathrm{Na}_{2} \mathrm{SeO}_{3}$ ) 0.18 mg; Mo (E-7) $\left(\left(\mathrm{NH}_{4}\right)_{6} \mathrm{Mo}_{7} \mathrm{O}_{24}\right) 1.2 \mathrm{mg} .{ }^{2}$ Maxiban G 160: $80 \mathrm{~g}$ Narasin and $80 \mathrm{~g}$ Nicarbazin per kg of product. ${ }^{3}$ Elancoban: $200 \mathrm{~g}$ Sodium Monensin per kg of product 
Table 2. Analysed nutrient contents of basal diet (as fed basis).

\begin{tabular}{|c|c|c|c|}
\hline \multirow{2}{*}{ Nutrient } & Starter & Grower & Finisher \\
\hline & $0-14 \mathrm{~d}$ & $15-28$ & $29-37 d$ \\
\hline $\mathrm{ME} \mathrm{MJ} / \mathrm{kg}^{1}$ & 12.13 & 12.55 & 12.55 \\
\hline $\mathrm{CP}$ g/kg & 209.7 & 203.5 & 184.4 \\
\hline Ether extract $\mathrm{g} / \mathrm{kg}$ & 51.9 & 68.8 & 79.9 \\
\hline Crude ash g/kg & 50.2 & 47.5 & 44.9 \\
\hline \multicolumn{4}{|l|}{ Amino acids $\mathrm{g} / \mathrm{kg}$} \\
\hline Lys & 13.2 & 11.4 & 10.6 \\
\hline $\mathrm{Met}^{2}$ & $2.70(2.70)$ & $2.50(2.60)$ & $2.30(2.50)$ \\
\hline Cys & 3.2 & 3.3 & 2.8 \\
\hline Thr & 8.1 & 7.6 & 7 \\
\hline $\operatorname{Trp}$ & 2.6 & 2.4 & 2.1 \\
\hline Arg & 12.9 & 11.8 & 11.5 \\
\hline Ile & 9.7 & 9.1 & 8.5 \\
\hline Leu & 15.6 & 14.6 & 13.8 \\
\hline Val & 9.9 & 9.9 & 9 \\
\hline Glu & 59.1 & 62.8 & 45.7 \\
\hline Phe & 9.1 & 8.9 & 8.3 \\
\hline His & 5 & 4.7 & 4.3 \\
\hline Asp & 17.4 & 18.2 & 16.8 \\
\hline Gly & 7.8 & 7.6 & 7.3 \\
\hline Ala & 9 & 8.6 & 8.2 \\
\hline Pro & 11.4 & 11.1 & 9.9 \\
\hline
\end{tabular}

${ }^{1} \mathrm{ME}$ contents were calculated based on WPSA [14]; ${ }^{2}$ Met contents in parenthesis are based on dietary formulation.

Table 3. Analysed contents of Met in dietary treatments.

\begin{tabular}{ccccc}
\hline \multirow{2}{*}{ Trt. } & \multicolumn{4}{c}{ Met source supplements (\%) } \\
\cline { 2 - 5 } & Expected suppl. level & Starter 0 - 14 d & Grower 15 - 28 d & Finisher 29 - 37 d \\
\hline Basal & - & - & - & - \\
L-Met1 ${ }^{1}$ & 0.05 & 0.04 & 0.05 & 0.04 \\
L-Met2 & 0.10 & 0.08 & 0.09 & 0.09 \\
L-Met3 & 0.15 & 0.13 & 0.14 & 0.15 \\
L-Met4 & 0.20 & 0.15 & 0.19 & 0.20 \\
DL-Met1 & 0.05 & 0.05 & 0.05 & 0.05 \\
DL-Met2 & 0.10 & 0.09 & 0.09 & 0.10 \\
DL-Met3 & 0.15 & 0.14 & 0.14 & 0.15 \\
DL-Met4 & 0.20 & 0.19 & 0.19 & 0.20
\end{tabular}

${ }^{1}$ L-Met: Procured from CJ Europe GmbH, Germany; ${ }^{2} \mathrm{DL}-$ Met: Procured from Sumitomo Chemical Company, Japan. 
feed conversion ratio (FCR) was calculated dividing the total feed consumed within the period to the weight gained by the live animals within the period plus the weight gain of the dead animals during the period. Average feed consumption was calculated as the product of weight gain (WG) and feed conversion ratio (FCR).

\subsection{Statistical Evaluation}

Results were analysed as a randomized complete block design by two way ANOVA with 6 blocks corresponding to location within the house and 9 treatments corresponding to the basal diet and each of the four levels of DL and L-Met. Treatment means were compared for significance $(P<0.05)$ using Tukey's test.

The RBV of DL and L-Met was calculated using the model of Littell et al. [17] to obtain the response coefficients by using SPSS (Version 24 for Windows; SPSS Inc., IBM, Chicago, IL).

$$
\mathrm{Y}=\mathrm{B} 1+\mathrm{B} 2 \times\left(1-\mathrm{e}^{(\mathrm{B} 31 \times \mathrm{X} 1+\mathrm{B} 32 \times \mathrm{X} 2)}\right)
$$

where $\mathrm{Y}=$ response variable (Feed intake, $\mathrm{BW}, \mathrm{ADG}$ and FCR,)

$\mathrm{B} 1=$ intercept (response of basal diet)

$\mathrm{B} 1+\mathrm{B} 2=$ asymptote

B31 = Steepness coefficient for L-Met

B32 $=$ Steepness coefficient for DL-Met

$\mathrm{X} 1$ = level of L-Met

$\mathrm{X} 2$ = level of DL-Met

The bioavailability for DL-Met relative to L-Met was calculated by the ratios of regression coefficients B31 and B32 according to Elwert et al. [18]. RBV $=100$ ${ }^{*} \mathrm{~B} 31 / \mathrm{B} 32$

\section{Results}

The statistical means for BW, FI, ADG and FCR attributed by two way ANOVA did not reveal any significant $(P>0.05)$ difference depending on the source of Met, however, the growth parameters for the basal diet were significantly $(P<$ 0.05) lower as compared to the experimental diets supplemented with Met (Table 4(a) and Table 4(b)). The body weight of birds increased gradually with the increase $(P<0.05)$ in supplementation of Met source, which indicates a clear deficiency of Met in the basal diet.

The growth response corresponding to L-Met supplementation in relation to DL-Met was numerically higher, but Tukey's test does not reveal significant $(P>$ 0.05) difference due to the different Met sources.

A curvilinear response was observed from $0-37 \mathrm{~d}$ for BW and FCR with graded Met supplementation (Figure 1) which was analysed by multi-exponential common plateau regression. The data of the present study appeared to fit well with the asymptotic nonlinear model and is considered to be adequate to compare the two sources. 
Table 4. (a) Statistical means of the performance parameters depending on source and dietary Met levels (0 - 14 and 15 - $28 \mathrm{~d}$ ); (b) Statistical means of the performance parameters depending on source and dietary Met levels (29- 37 and $0-37 \mathrm{~d}$ ).

(a)

\begin{tabular}{|c|c|c|c|c|c|c|c|c|c|c|}
\hline \multirow{3}{*}{ Trt. } & \multirow{3}{*}{ Met\% } & \multicolumn{4}{|c|}{$0-14 \mathrm{~d}$} & \multirow{3}{*}{ Met $\%$} & \multicolumn{4}{|c|}{$15-28 d$} \\
\hline & & FI & BW & $\mathrm{ADG}$ & FCR & & FI & BW & $\mathrm{ADG}$ & FCR \\
\hline & & $\mathrm{g}$ & $\mathrm{g}$ & g & $\mathrm{g} / \mathrm{g}$ & & g & $\mathrm{g}$ & g & $\mathrm{g} / \mathrm{g}$ \\
\hline $\mathrm{BD}$ & 0 & $22.10^{\mathrm{a}}$ & $252^{\mathrm{a}}$ & $14.90^{\mathrm{a}}$ & $1.48^{\mathrm{a}}$ & 0 & $75.76^{\mathrm{a}}$ & $742^{\mathrm{a}}$ & $32.60^{\mathrm{a}}$ & $2.32^{\mathrm{a}}$ \\
\hline L-Met1 & 0.04 & $31.40^{\mathrm{b}}$ & $392^{\mathrm{b}}$ & $24.90^{\mathrm{b}}$ & $1.26^{\mathrm{b}}$ & 0.05 & $109.30^{\mathrm{b}}$ & $1383^{\mathrm{b}}$ & $66.00^{\mathrm{b}}$ & $1.65^{\mathrm{b}}$ \\
\hline L-Met2 & 0.08 & $35.30^{c}$ & $447^{\mathrm{c}}$ & $28.80^{c}$ & $1.22^{\mathrm{bc}}$ & 0.09 & $119.20^{c}$ & $1674^{c}$ & $81.80^{c}$ & $1.45^{\mathrm{c}}$ \\
\hline L-Met3 & 0.13 & $35.70^{c}$ & $457^{\mathrm{c}}$ & $29.50^{c}$ & $1.21^{\mathrm{c}}$ & 0.14 & $123.30^{\mathrm{c}}$ & $1749^{\mathrm{d}}$ & $86.10^{\mathrm{d}}$ & $1.43^{\mathrm{c}}$ \\
\hline L-Met4 & 0.15 & $35.90^{c}$ & $464^{\mathrm{c}}$ & $30.00^{c}$ & $1.19^{c}$ & 0.19 & $126.00^{c}$ & $1798^{\mathrm{d}}$ & $88.90^{\mathrm{d}}$ & $1.41^{\mathrm{c}}$ \\
\hline DL-Met1 & 0.05 & $31.50^{\mathrm{b}}$ & $400^{\mathrm{b}}$ & $25.50^{\mathrm{b}}$ & $1.24^{\mathrm{bc}}$ & 0.05 & $112.50^{\mathrm{b}}$ & $1375^{\mathrm{b}}$ & $64.90^{\mathrm{b}}$ & $1.73^{\mathrm{b}}$ \\
\hline DL-Met2 & 0.09 & $34.60^{c}$ & $445^{\mathrm{c}}$ & $28.70^{c}$ & $1.21^{\mathrm{c}}$ & 0.09 & $122.40^{\mathrm{c}}$ & $1675^{\mathrm{c}}$ & $82.00^{c}$ & $1.49^{\mathrm{c}}$ \\
\hline DL-Met3 & 0.14 & $35.60^{c}$ & $458^{\mathrm{c}}$ & $29.60^{c}$ & $1.20^{\mathrm{c}}$ & 0.14 & $122.70^{c}$ & $1747^{\mathrm{d}}$ & $85.90^{\mathrm{d}}$ & $1.42^{\mathrm{c}}$ \\
\hline DL-Met4 & 0.19 & $36.10^{c}$ & $454^{\mathrm{c}}$ & $29.30^{c}$ & $1.24^{\mathrm{c}}$ & 0.19 & $123.40^{\mathrm{c}}$ & $1767^{\mathrm{d}}$ & $87.50^{\mathrm{d}}$ & $1.41^{\mathrm{c}}$ \\
\hline
\end{tabular}

${ }^{\mathrm{a}-\mathrm{c} C}$ Columns with different superscripts are statistically significant $(\mathrm{P}<0.05)$; Trt $=$ experimental treatment; Met\% = supplemental methionine as a percent; FI = Average daily feed intake; BW = Live body weight; $\mathrm{ADG}=$ Average daily gain; $\mathrm{FCR}=$ Feed conversion ratio.

(b)

\begin{tabular}{|c|c|c|c|c|c|c|c|c|c|}
\hline \multirow{3}{*}{ Trt. } & & \multicolumn{4}{|c|}{$29-37 d$} & \multicolumn{4}{|c|}{$0-37 d$} \\
\hline & & FI & BW & $\mathrm{ADG}$ & FCR & FI & BW & $\mathrm{ADG}$ & FCR \\
\hline & & g & g & g & $\mathrm{g} / \mathrm{g}$ & $\mathrm{g}$ & $\mathrm{g}$ & g & $\mathrm{g} / \mathrm{g}$ \\
\hline $\mathrm{BD}$ & 0 & $113.00^{\mathrm{a}}$ & $1137^{\mathrm{a}}$ & $49.40^{\mathrm{a}}$ & $2.28^{\mathrm{a}}$ & $63.50^{\mathrm{a}}$ & $1137^{\mathrm{a}}$ & $29.50^{\mathrm{a}}$ & $2.15^{\mathrm{a}}$ \\
\hline L-Met1 & 0.04 & $177.90^{\mathrm{b}}$ & $2168^{b}$ & $98.10^{\mathrm{b}}$ & $1.81^{\mathrm{b}}$ & $94.60^{\mathrm{b}}$ & $2168^{b}$ & $57.40^{\mathrm{b}}$ & $1.64^{\mathrm{b}}$ \\
\hline L-Met2 & 0.09 & $196.60^{c}$ & $2552^{c}$ & $109.60^{\mathrm{c}}$ & $1.79^{\mathrm{bc}}$ & $104.10^{c}$ & $2552^{c}$ & $67.80^{c}$ & $1.53^{\mathrm{c}}$ \\
\hline L-Met3 & 0.15 & $200.50^{c}$ & $2683^{d}$ & $116.70^{\mathrm{d}}$ & $1.72^{\mathrm{bc}}$ & $106.80^{c}$ & $2683^{\mathrm{d}}$ & $71.30^{\mathrm{d}}$ & $1.49^{\mathrm{c}}$ \\
\hline L-Met4 & 0.2 & $201.80^{c}$ & $2747^{\mathrm{d}}$ & $118.40^{\mathrm{d}}$ & $1.70^{\mathrm{c}}$ & $108.20^{c}$ & $2746^{\mathrm{d}}$ & $73.00^{\mathrm{d}}$ & $1.48^{\mathrm{c}}$ \\
\hline DL-Met1 & 0.05 & $180.00^{\mathrm{b}}$ & $2162^{\mathrm{b}}$ & $98.40^{\mathrm{b}}$ & $1.83^{\mathrm{b}}$ & $96.40^{\mathrm{b}}$ & $2162^{\mathrm{b}}$ & $57.20^{\mathrm{b}}$ & $1.68^{\mathrm{b}}$ \\
\hline DL-Met2 & 0.1 & $199.10^{c}$ & $2562^{c}$ & $110.80^{c}$ & $1.79^{\mathrm{bc}}$ & $105.80^{c}$ & $2562^{c}$ & $68.00^{c}$ & $1.55^{\mathrm{c}}$ \\
\hline DL-Met3 & 0.15 & $200.50^{c}$ & $2672^{\mathrm{d}}$ & $115.50^{\mathrm{d}}$ & $1.74^{\mathrm{bc}}$ & $106.40^{c}$ & $2672^{\mathrm{d}}$ & $71.00^{\mathrm{d}}$ & $1.49^{c}$ \\
\hline DL-Met 4 & 0.2 & $199.00^{c}$ & $2698^{\mathrm{d}}$ & $116.20^{\mathrm{d}}$ & $1.71^{c}$ & $107.10^{c}$ & $2698^{d}$ & $71.70^{\mathrm{d}}$ & $1.49^{c}$ \\
\hline
\end{tabular}

${ }^{\mathrm{a}-\mathrm{d}}$ Columns with different superscripts are statistically significant $(P<0.05)$.

The RBV of DL to L-Met was calculated by the ratio of B32/B31 as described in Equation 1. The results of RBV of DL-Met through the study period are summarized in Table 5 and demonstrated in Figure 1. The parameter estimates are described in Table 6. RBV of DL-Met across the study period was for FI: 99, BW: 89, ADG: 99 and FCR: 77. 


\section{Discussion}

Based on ANOVA, the statistical non-significant differences $(P>0.05)$ on performance parameters depending on Met sources may be attributed to the difference in calculated and analysed contents of the dietary treatments of L-Met, which were found lower than expected (Table 3). In contrast, test diets containing DL-Met, the expected and calculated values of Met were in good agreement.

It is difficult to ascertain the level of one source over the other when two different sources of the test product are supplemented at closer levels [19]. The

Table 5. Summary of relative bioavailability (RBV) of DL-Met according to various response criteria from 0 - $37 \mathrm{~d}$ (\%, L-Met: 100) RBV $=100 * \mathrm{~B} 31 / \mathrm{B} 32$.

\begin{tabular}{ccc}
\hline Criterion of response & RBV & 95\% Confidence interval \\
\hline Feed intake & 99 & $71-128$ \\
Body weight & 89 & $78-100$ \\
Average daily gain & 89 & $78-100$ \\
Feed to gain & 77 & $51-103$ \\
\hline
\end{tabular}
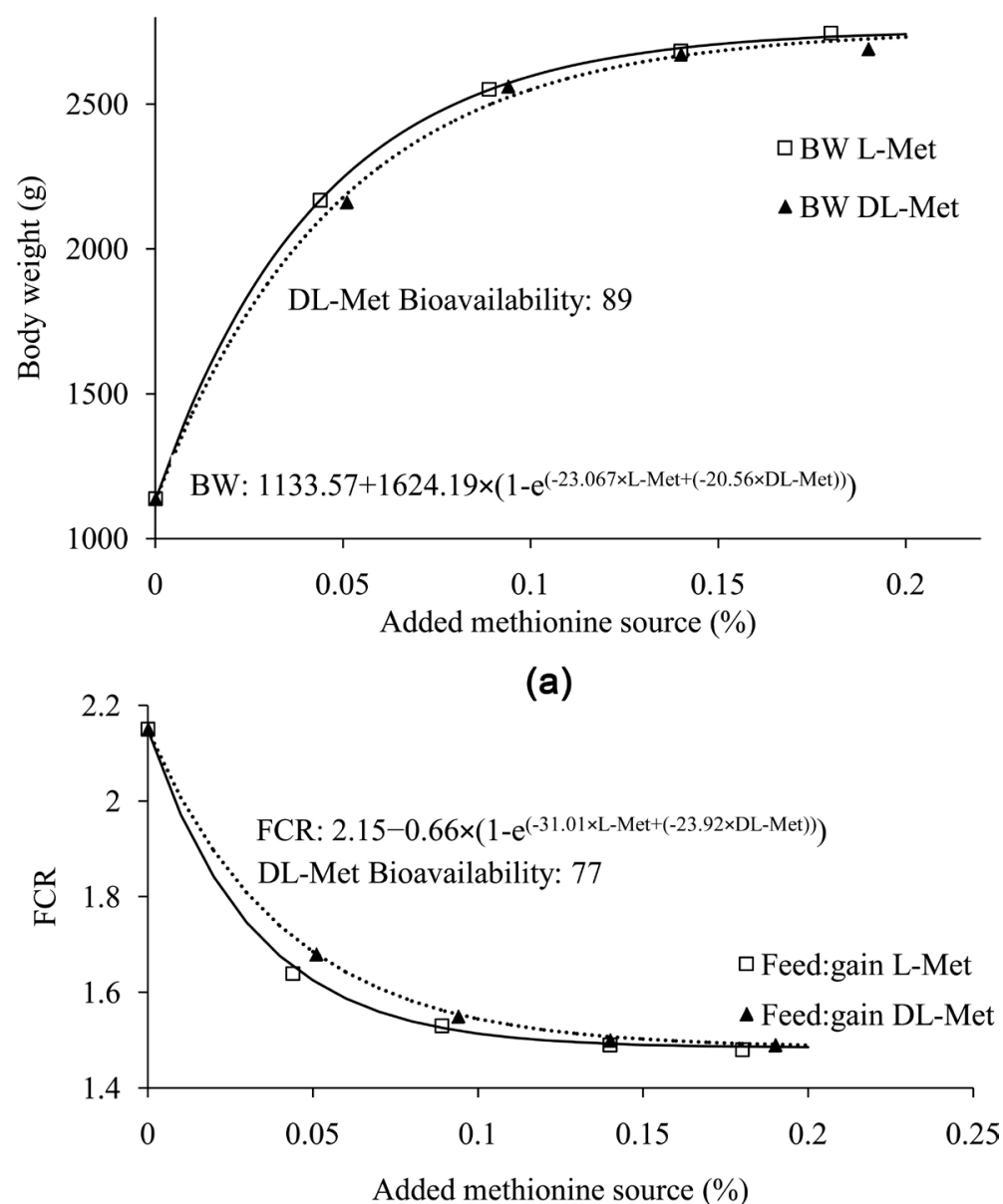

(b)

Figure 1. Body weight (a) and FCR (b) of chickens at 37 days of age feeding different levels of DL and L-Met. 
Table 6. Parameters of nonlinear regression model describing relationship between response criteria at different supplementation levels of DL and L-Met (0 - 37).

\begin{tabular}{|c|c|c|c|c|c|c|}
\hline \multirow{2}{*}{ Criteria of response } & \multirow{2}{*}{ Parameter } & \multirow{2}{*}{ Estimate } & \multirow{2}{*}{ Standard error } & \multicolumn{2}{|c|}{$95 \%$ confidence interval } & \multirow{2}{*}{$\mathrm{R}^{2}$} \\
\hline & & & & Lower & Upper & \\
\hline \multirow{4}{*}{ Feed intake $(\mathrm{g})$} & B1 & 63.442 & 1.864 & 59.697 & 67.187 & \multirow{4}{*}{0.90} \\
\hline & B2 & 44.504 & 2.077 & 40.332 & 48.677 & \\
\hline & B31 & -27.477 & 3.503 & -34.513 & -20.441 & \\
\hline & B32 & -27.4 & 3.68 & -34.792 & -20.009 & \\
\hline \multirow{4}{*}{ Body weight (g) } & B1 & 1133.57 & 34.051 & 1065.18 & 1201.96 & \multirow{4}{*}{0.97} \\
\hline & B2 & 1624.19 & 38.776 & 1546.31 & 1702.07 & \\
\hline & B31 & -23.067 & 1.493 & -26.066 & -20.069 & \\
\hline & B32 & -20.56 & 1.297 & -23.165 & -17.955 & \\
\hline \multirow{4}{*}{ Average daily gain (g) } & B1 & 29.467 & 0.92 & 27.618 & 31.315 & \multirow{4}{*}{0.93} \\
\hline & B2 & 43.897 & 1.048 & 41.792 & 46.002 & \\
\hline & B31 & -23.067 & 1.493 & -26.066 & -20.069 & \\
\hline & B32 & -20.56 & 1.297 & -23.165 & -17.955 & \\
\hline \multirow{4}{*}{ Feed to gain } & B1 & 2.149 & 0.033 & 2.083 & 2.215 & \multirow{4}{*}{0.87} \\
\hline & B2 & -0.665 & 0.037 & -0.739 & -0.591 & \\
\hline & B31 & -31.018 & 4.97 & -41.001 & -21.034 & \\
\hline & B32 & -23.926 & 3.513 & -30.982 & -16.869 & \\
\hline
\end{tabular}

B1 = intercept (response of basal diet); B1 + B2 = asymptote; B31 = Steepness coefficient for L-Met; B32 = Steepness coefficient for DL-Met.

study remained indecisive to quantify one sources over the other without affecting the performance parameters.

Studies conducted by Zelenka et al. [20] about the performance parameters of broilers, revealed similar findings, as of present experiment, through the application of ANOVA. They compared the DL-Met with MHA with graded levels of Met dietary concentration. The data for whole experiment showed better FCR and body weight in DL-Met treatment groups, however, the results were statistically non-significant $(P>0.05)$ over the MHA counterparts.

In a metabolic experiment for 20 days in post weaned growing pigs, Shen et al. [21] used the mixed model of SAS with completely randomized design, and observed a nonlinear response for growth parameters like ADG $(P=0.087)$, FCR and reduced plasma urea nitrogen (PUN) in L-Met as compared to DL-Met.

Whereas, Kong et al. [22] compared the both Met isomers in a nitrogen balance experiment with weaned piglets. Final BW, N intake, faecal N, Urinary N and apparent $\mathrm{N}$ digestibility were observed in L-Met vs. DL-Met using orthogonal polynomial contrast analysis and observed no response $(P>0.05)$ in performance parameters.

ANOVA appears to be insufficient for the above mentioned as well as the present study to estimate the difference between the closely matching treat- 
ments. Moreover, two-way ANOVA also suffers from some limitations related to the present study, for instance it considers the levels of Met as categorical, while in fact they are continuous.

Therefore, the non-linear model of Littell et al. [17] was adopted to estimate the RBV. This model was questioned by Rosen [23] who states that "nutrient response curves are inevitably quadratic". When the quadratic model was applied to our data, the curve shows a maxima below the $0.20 \%$ level of Met which the data do not justify, as there seems to be further response beyond the $0.15 \%$ level. Furthermore, the quadratic model was proposed by Kratzer and Littell [24] for DL-Met and DL-MHA, in which different maxima are achieved depending on the Met source which has later been criticized by Piepho [25] and Elwert et al. [18]. The hypothesis of different plateaus does not seem reasonable if one evaluates the response to the same nutrient, because the maximum should be the same for different sources. The data of the present study seemed to fit, in most cases, the asymptotic non-linear model was considered to be adequate to compare the two sources.

The RBV estimated in the present study is in agreement with the dose response studies of Noll et al. [26]. They conducted in total three experiments in large white turkeys from 7-28 days. L-Met (100\%) and Met hydroxy analoguefree acid (88\%) were evaluated for biopotency compared to DL-Met (99\%) in a starter diet. The Met levels of supplementation were $0 \%, 0.04 \%, 0.10 \%, 0.16 \%$, $0.28 \%, 0.44 \%$, and $1.00 \%$.

They observed that the level of Met effected the growth of the birds significantly $(P<0.05)$. Based on the three studies the biopotency $( \pm \mathrm{SE})$ of L-Met was significantly superior to DL-Met $(131 \% \pm 10 \%)$; the biopotency of the analogue was not significantly different from DL-Met $(96 \% \pm 7 \%)$. In the present study, as a whole (37d), the RBV of DL- and L-Met was considerably diverse as compared to the observation of Noll et al. [26]. These dissimilarities in RBV can be attributed to difference in species of animals and age period of animals during the study.

The difference in exponential graphic curves (Figure 1) is widened at lower Met levels. As the Met supplementation approaches to requirement or above the two curves inclined to converge. The presented observation is in accordance to the study of Katz and Baker [10], who conducted four experiments in young growing chickens to determine the relative efficacy of DL, L- and D-Met. They observed that L-Met supported faster and more efficient gains than D- or DL-Met when fed at levels below the requirement. However, when different sources supplemented up the level of requirement, equal efficacy was attained. They concluded that at lower levels of supplementation, L-Met is a better source of sulphur amino acids than D-Met. They also concluded that L- and D-Met appear to have equal efficacy when incorporated into diets that are only marginally deficient in sulphur-bearing amino acids.

The RBV for body weight, DL-Met $=89$, is in contrast with the observations 
of Dilger et al. [10] who determined the relative bioefficacy of Met precursor compounds in young chicks. They compared the DL-Met with the L-Met precursor (2-keto-4-(methylthio) butyric acid) using Met-deficient diets of differing composition. Based on weight gain they concluded the relative bioefficacy values of $98.5 \%$ and $89.3 \%$ for DL-Met and keto-Met respectively. The difference in RBV for L-Met may attributed to the intermediated precursor (Keto-Met) which needs to be converted into L-Met through the transamination process in order to come in to the metabolic pathway. Moreover, the RBV of the L-Met concluded by Shen et al. [21] was higher than that of the present study. They reported the RBV of L-Met as $159 \%$ to $100 \%$ of DL-Met for AGD and $138.5 \%$ to $100 \%$ for FCR respectively in weaned piglets. Recently, Kong et al. [22] determined the bioavailability of D-Met relative to L-Met for nursery pigs using the slope-ratio assay. They concluded that the mean relative bioequivalence of D- to L-Met was $87.6 \%$ based on urinary $\mathrm{N}$ output or $89.6 \%$ based on $\mathrm{N}$ retention. These values closely matched to the present study in which the RBV for DL-Met $=89$, although, the difference in the species of the animals cannot be ignored.

\section{Conclusion}

Statistically, when comparing if one source (DL-Met) "equivalent" to the reference (L-Met) ignoring the type II error could have important practical consequences. D-Met must be converted to L-Met in the body. The process requires different steps, and it is not clear that process is $100 \%$ efficient; this may be projected through performance parameters. In the present experiment the RBV of DL to L-Met was 89:100 for BW and 77:100 for FCR.

\section{References}

[1] Esteve-Garcia, E. and Austic, R.E. (1993) Intestinal Absorption and Renal Excretion of Dietary Methionine Sources by the Growing Chicken. Journal of Nutritional Biochemistry, 4, 576-587. https://doi.org/10.1016/0955-2863(93)90026-S

[2] Grau, C.R. and Almquist, H.J. (1943) The Utilization of the Sulphur Amino Acids by the Chick. Journal of Nutrition, 26, 631-640. https://doi.org/10.1093/jn/26.6.631

[3] Fell, R.V., Wilkerson, W.S. and Watts, A.B. (1959) The Utilization by the Chick of D- and L-Amino Acids in Liquid and Dry Diets. Poultry Science, 38, 1203-1204.

[4] Leveille, G.A., Shapiro, R. and Fisher, H. (1960) Amino Acid Requirements for Maintenance of the Adult Rooster. Journal of Nutrition, 72, 8-15. https://doi.org/10.1093/jn/72.1.8

[5] Brüggeman, J., Drepper, K. and Zucker, H. (1964) Quantitative Bestimmung der Verwertung von D-, L-, DL-Methionine und Ca-DL-2-hydroxy-4-methylthiobutyrat durch das Hüner Küken. Natturwissenschaften, 49, 334.

https://doi.org/10.1007/BF00602214

[6] Smith, R.E. (1966) The Utilization of L-Methionine, DL-Methionine and Methionine Hydroxy Analogue by the Growing Chick. Poultry Science, 45, 571-577. https://doi.org/10.3382/ps.0450571

[7] Gutteridge, D.G.A. and Lewis, D. (1964) Chick Bioassay of Methionine and Cytosine. II. Assay of Soybean Meals, Ground and Nut Meals, Meat Meals, Methionine 
Isomers and Methionine Analogue. British Poultry Science, 5, 193-200. https://doi.org/10.1080/00071666408415532

[8] Dilger, R., Kobler, N.C., Weckbecker, C., Hoehler, D. and Baker, D.H. (2007) 2-Keto-4-(Methylthio)Butyric Acid (Keto Analog of Methionine) Is a Safer and Efficacious Precursor of L-Methionine in Chicks. Journal of Nutrition, 137, 1868-1873. https://doi.org/10.1093/jn/137.8.1868

[9] Marret, L., Bird, H.R. and Sunde, M.L. (1964) The Effects of Different Isomers of Methionine on Growth of Chicks Fed Amino Acid Diets. Poultry Science, 43, 1113-1118. https://doi.org/10.3382/ps.0431113

[10] Katz, R.S. and Baker, D.H. (1975) Efficacy of D- L- and DL-Methionine for Growth of Chicks Fed Crystalline Amino Acid Diets. Poultry Science, 54, 1667-1674. https://doi.org/10.3382/ps.0541667

[11] Tipton, H.C., Dilworth, B.C. and Day, E.J. (1966) A Comparison of D-, L- and DL-Methionine and Methionine Analogue Calcium in Chick Diets. Poultry Science, 45, 381-387. https://doi.org/10.3382/ps.0450381

[12] European Union (2010) Directive 63 of the European Parliament and of the Council of 22 September on the Protection of Animals Used for Scientific Purposes. Official Journal of European Union L, 276, 33.

[13] Aviagen, T. (2014) Ross 308 Broiler Nutrition Specifications. Aviagen Group, Huntsville.

http://en.aviagen.com/assets/Tech_Center/Ross_Broiler/Ross-308-Broiler-Nutrition -Specs-2014r17-EN.pdf

[14] WPSA. World's Poultry Science Association (1984) The Prediction of Apparent Metabolizable Energy Values for Poultry in Compound Feeds. World s Poultry Science Journal, 40, 181-182.

[15] AOAC (2000) Official Methods of Analysis. 17th Edition, Association of Official Analytical Chemists Washington DC.

[16] Naumann, C. and Bassler, R. (1997) Die chemischen Untersuchungen von Futtermitteln. Methodenbuch, Volume III, Kapital 4.11.1. Aminosäuren, VDLUFA-Verlag, Darmstadt.

[17] Littell, R.C., Henry, P.R., Lewis, A.J. and Ammerman, C.B. (1997) Estimation of Relative Bioavailability of Nutrients using SAS Procedures. Journal of Animal Science, 75, 2672-2683. https://doi.org/10.2527/1997.75102672x

[18] Elwert, C., De abreu fernandes, E. and Lemme, A. (2008) Biological Effectiveness of Methionine Hydroxyl-Analogue Calcium Salt in Relation to DL-Methionine in Broiler Chickens. Asian-Australasian Journal of Animal Sciences, 21, 1506-1515. https://doi.org/10.5713/ajas.2008.80201

[19] Hoehler, D. (2006) No Evidence of Different Dose Responses of Commercial Methionine Sources in Broiler. Poultry Science, 85, 2047. https://doi.org/10.1093/ps/85.12.2047

[20] Zelenka, J., Heger, J., Machander, V., Wiltafsky, M. and Lestak, M. (2013) Bioavailability of Liquid Methionine Hydoxyanalogue-Free Acid Relative to DL-Methionine in Broilers. Acta Universitatis Agriculturae et Silviculturae Mendelianae Brunensis, 61, 1513-1520. https://doi.org/10.11118/actaun201361051513

[21] Shen, Y.B., Weaver, A.C. and Kim, S.W. (2014) Effect of Feed Grade L-Methionine on Growth Performance and Gut Health in Nursery Pigs Compared with Conventional DL-Methionine. Journal of Animal Science, 92, 5530-5539. https://doi.org/10.2527/jas.2014-7830 
[22] Kong, C., Park, C.S., Ahn, J.Y. and Kim, B.G. (2016) Relative Bioavailability of DL-Methionine Compared with L-Methionine Fed to Nursery Pigs. Animal Feed Science and Technology, 215,181-185.

https://doi.org/10.1016/j.anifeedsci.2016.03.011

[23] Rosen, G.D. (2007) Nutritive Values of Methionine Sources. Poultry Science, 86, 209-210. https://doi.org/10.1093/ps/86.2.209

[24] Kratzer, D.D. and Littell, R.C. (2006) Appropriate Statistical Methods to Compare Dose Response to Methionine Sources. Poultry Science, 85, 947-954. https://doi.org/10.1093/ps/85.5.947

[25] Piepho, H.P. (2006) A Cautionary Note on Appropriate Statistical Methods to Compare Dose Responses to Methionine Sources. Poultry Science, 85, 1511-1512.

[26] Noll, S.L., Waibel, P.E., Cook, R.D. and Witmer, J.A. (1984) Biopotency of Methionine Sources for Young Turkeys. Poultry Science, 63, 2458-2470.

https://doi.org/10.3382/ps.0632458 